\title{
Photodegradation Effects in Materials Exposed to High Flux Solar and Solar Simulated Radiation
}

\author{
A. Ignatiev \\ University of Houston \\ Houston, Texas
}

NREL Technical Monitor: R. Gerald Nix

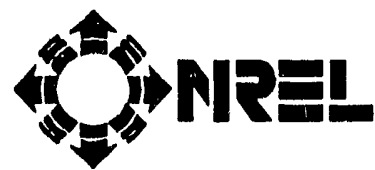

National Renewable Energy Laboratory

(formerly the Solar Energy Research Institute) 1617 Cole Boulevard Golden, Colorado 80401-3393

A Division of Midwest Research Institute Operated for the U.S. Department of Energy under Contract No. DE-AC02-83CH10093

Prepared under Subcontract No. X-7-07028-1

April 1992 
This report describes subcontracted research. The report is unrevlewed and expresses enly the opinions of the author[s]. It has been prepared for reproduction from the best available copy.

\title{
NOTICE
}

This report was prepared as an account of work sponsored by an agency of the United States government. Neither the United States government nor any agency thereof, nor any of their employees, makes any warranty, express cr implied, or assumes any legal liability or responsibility for the accuracy. completeness, or usefulness of any information, apparatus, product, or process disclosed, or represents that its use would not infringe privately owned rights. Reference herein to any specific commercial product, process, or service by trade name, trademark, manufacturer, or otherwise does not necessarily constitute or imply its endorsement, recommendation, or favoring by the United States government or any agency thereof. The views and opinions of authors expressed herein do not necessarily state or reflect those of the Uniied States government or any agency thereof.

\author{
Printed in the United States of America \\ Available from: \\ National Techniral Intcrmation Service \\ U.S. Department of Commerce \\ 5285 Port Roya! Road \\ Springfield, VA 22161 \\ Price: Microtiche A01 \\ Printed Copy $\mathrm{AO}$
}

Codes are used for pricing all pubiications. The code is determined by the number of pages in the publication. Information pertaining to the pricing codes can be found in the current issue ui the following publications which are generally available in most libraries: Energy Research Abstracts (ERA); Govern. ment Reports Announcements and Index (GRA and 1): Scientific and Technical Abstract Reports (STAR); and publication NTIS.PR-360 available from NTIS at the above aúditess. 


\section{TABLE OF CONIENTS}

Introduction . . . . . . . . . . . . . . 2

Historical Perspective . . . . . . . . . . . . . 3

High Flux Effects in letals . . . . . . . . . . . . . 4

Surnary . . . . . . . . . . . . . . . 18

Acknowledgenents . . . . . . . . . . . . . . . . . . . . 19

Publications Resulting from This Research . . . . . . . . . 20 


\section{INTRODUCTION}

The stability of materials under high flux solar radiation ( 1 $\mathrm{MW} / \mathrm{m}^{2}$ ) has recently been a point of interest in materials research. Usually, this high solar flux environment has been connected with high temperatures $\left(350-600{ }^{\circ} \mathrm{C}\right)$, however, this enhanced temperature regime is not the sole factor in degradation of materials under high flux irradiation. Under high flux irradiation, a material is exposed to concentrated radiation of wavelengths from - $0.3 \mathrm{um}$ to $-2 \mathrm{um}$. Radiation from this spectrum is by and large absorbed over a shallower depth ( up to a factor of 100 to 1000 times shallower) than infrared radiation; this surface localized absorption can lead to a surface temperature much higher than the measured bulk temperature. In addition, the ultraviolet and near ultraviolet components of the solar radiation may induce various chemicai changes at the surface of the material. Such changes are based in the energetic nature of the photons associated with solar radiation ( $0.5 \mathrm{eV}$ to $4 \mathrm{eV})$.

Both such surface localized and photon specific effects have been observed and characterized in the study of the interaction of high flux solar and solar simulated radiation with materials. The results of these studies will be enumerated in this report. 
HISTORICAL PERSPECTIVE

The first indications of photoeffects in solar energy relevant materials were in the Black Chrome solar absorber system studied by us in the early part of this research program. The Black chrome system is an absorber system that has its basis in the solar selective nature of its optical absorption due to the particulate nature of the Black chrome material. The composition of the coating is principally chromium particles with $\mathrm{Cr}_{2} \mathrm{O}_{3}$ skins. The high temperature $\left(T>400^{\circ} \mathrm{C}\right)$ degradation of the coating is based in the further oxidation of the particles, changing the composition of the coating and as a result changing optical response.

High flux solar irradiation $\left(\sim 1 \mathrm{MW} / \mathrm{m}^{2}\right)$ of the coatings to elevated temperatures of from 350 to $550^{\circ} \mathrm{C}$ resulted, however, in reduction of the optical degradation of the coating. subsequent analysis of the chemical composition of the coating indicated major reduction of oxidation of the chrome particles. Further studies determined that this reduction was the direct result of the photodesorption process. Within this mechanism, solar photons of energy greater than a certain threshold ( usually of the order of 2 to $3 \mathrm{eV}$ ) can excite a surface complex causing it to no longer be bound to the surface. This complex then desorbs from the surface and changes the chemical composition of the surface. Within the Black Chrome system, the surface complexes were principally $\mathrm{CO}$ and $\mathrm{CO}_{2}$, and their photodesorption caused a reduc- 
tion of the oxygen content of the surface. This reduction, therefore, reduced the rate of oxidation of the Black chrome under high flux solar irradiation, with the flux intensity (the number of photons $/ \mathrm{cm}^{2} \mathrm{sec}$ ) defining the extent of oxidation reduction in the material.

As noted, this was the first observation of the effect of high solar fluxes on the stability of materials, and in fact indicated a beneficial component to high flux irradiation. The studies were, however, on solar absorber materials and it was of interest to determine the effect of high solar fluxes on the stability of other solar relevant materials.

HIGH FLUX EFFECTS IN METALS

Aluminum has been significantly used in solar technology both as a reflector material and as a structural material. Its response to high flux solar irradiation was critically investigated in our studies and resulted in rather interesting conclusions.

As shown in Fig. 1, oxide thicknesses between infrared heated and high flux irradiated aluminum samples are quite different. However, the variances seem different than expected. As previously discussed, solar radiation is expected to be preferentially absorbed in the surface region of a material (especially a metal which has a high imaginary component of the index of refraction). As a result, a material should experience a surface 

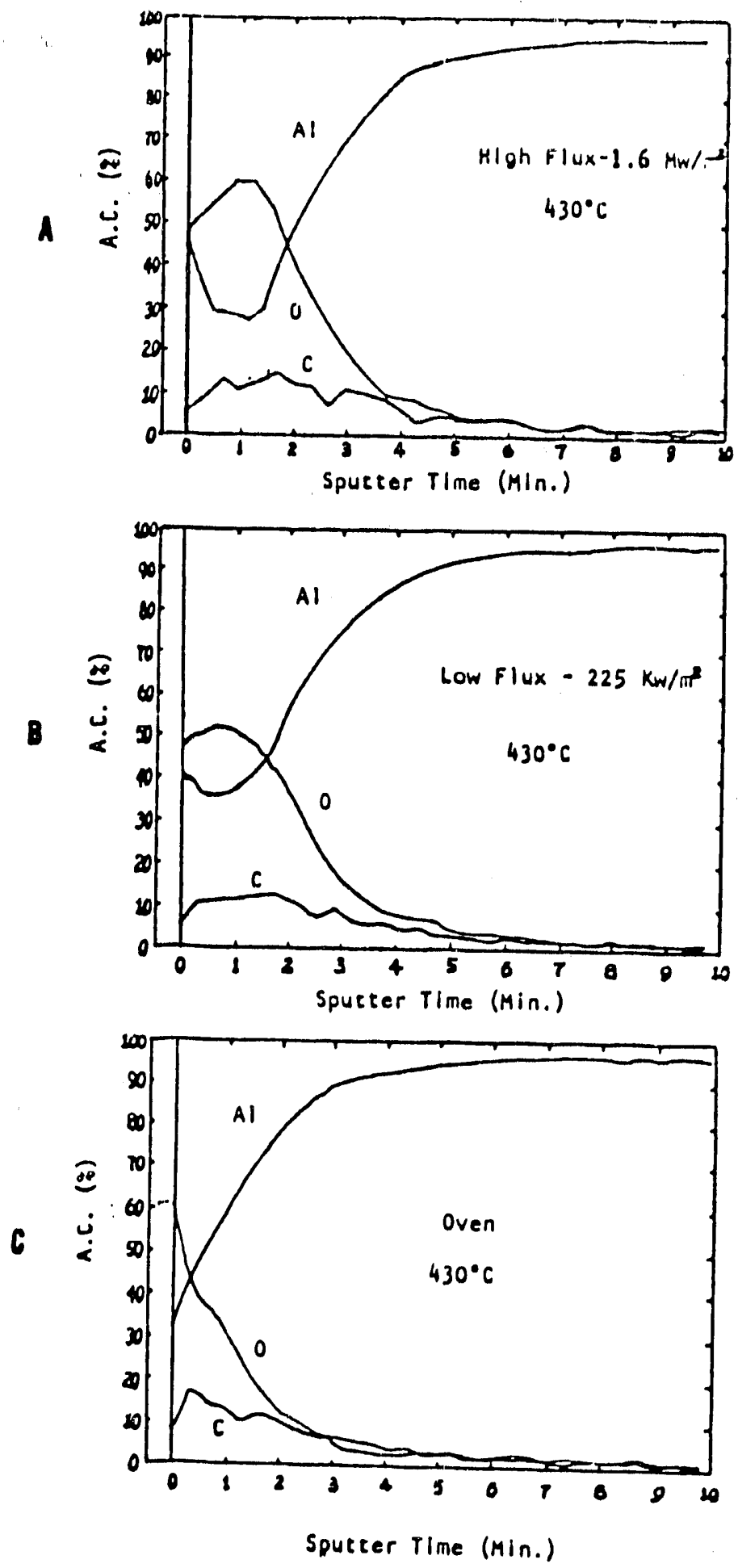

Fig. 1. AES depth profiles giving the atomic concentrations of oxygen, aluminum and carbon for aluminum samples heated for 135 minutes at $430^{\circ} \mathrm{C}$ using different techniques. 
temperature that is higher than that of the bulk, and hence in the case of a metal, should exhibit greater oxidation when irradiated in air. Fig. 1 shows just the opposite - that the oxide thickness of the high flux irradiated $\left(>1 \mathrm{MW} / \mathrm{m}^{2}\right)$ aluminum sample is less than that of the infrared irradiated sample. This paradox was rectified through the study of aluminum oxidation kinetics which showed that the rate of oxidation of aluminum decreases above $550^{\circ} \mathrm{C}$. The measured decrease of oxide thickness at $500{ }^{\circ} \mathrm{C}$ (bulk measured temperature) under solar irradiation as compared to infrared irradiation, therefore, indicates surface temperatures under solar irradiation as being higher by about 100 ${ }^{\circ} \mathrm{C}$ than the bulk measured temperatures. This was however, an indirect measure of surface temperature difference under high flux irradiation. More quantitative measure will be seen in the report of the high flux work on nickel.

Additional high flux studies on aluminum have shown that photodesorption of surface localized oxygen and carbon in the forms of $\mathrm{CO}$ and $\mathrm{CO}_{2}$ also occurs. This process not only further: reduces the surface oxide thickness, but also increases the aluminum content at the surface thereby increasins the absorptance of the surface region further enhancing the surface absorption of the high flux solar radiation.

Since photodesorption of surface localized species was observed on the aluminum surface, the photodesorption process was further studied to determine the exact desorption mechanism. $\mathrm{CO}, \mathrm{CO}_{2}, \mathrm{O}_{2}$ 
and $\mathrm{H}_{2} \mathrm{O}$ were adsorbed on the aluminum surface and the system exposed to high flux solar simulated radiation. It was determined that a threshold for photodesorption on aluminum was $-3.65 \mathrm{eV}$; and that solar photons significantly affect surface chemistry. As an example, it was determined that $\mathrm{CO}_{2}$ was desorbed from a surface under photo-irradiation when only co was adsorbed, i.e., the solar photons were effective in catalyzing the surface adsorbed $\mathrm{CO}$ molecules to $\mathrm{CO}_{2}$ and desorbing that specie. This was the first observation of high flux photo-enhanced catalysis active at a surface and formed the basis for significant follow-on work in high flux enhanced catalytic reactions.

Stainless-type steels form the basis for a major category of materials utilized in the solar industry. The stainless steels are, however, relatively complex alloys, and as a result, the individual components of the alloys were studied as to their response to high flux solar irradiation.

Both chromiurn and iron showed minor oxidation enhancements under high flux irradiation. Iron showed oxide thickness enhancements of the order of 8 to $30 \%$ under irradiation of from 0.6 to 1.6 $\mathrm{MW} / \mathrm{m}^{2}$ and temperatures of 300 to $500{ }^{\circ} \mathrm{C}$. Chromium showed very similar behavior with the additional complication of significant photodesorption of $\mathrm{CO}$ and $\mathrm{CO}_{2}$. The desorption yields were relatively large for $\mathrm{Cr}_{2} \mathrm{O}_{3}$ which had carbon contamination present $\left(\sim 5 \times 10^{-4}\right.$ to $\left.1 \times 10^{-3} \mathrm{~mol} / \mathrm{photon}\right)$. This behavior is quite similar to that observed initially for Black chrome where the 


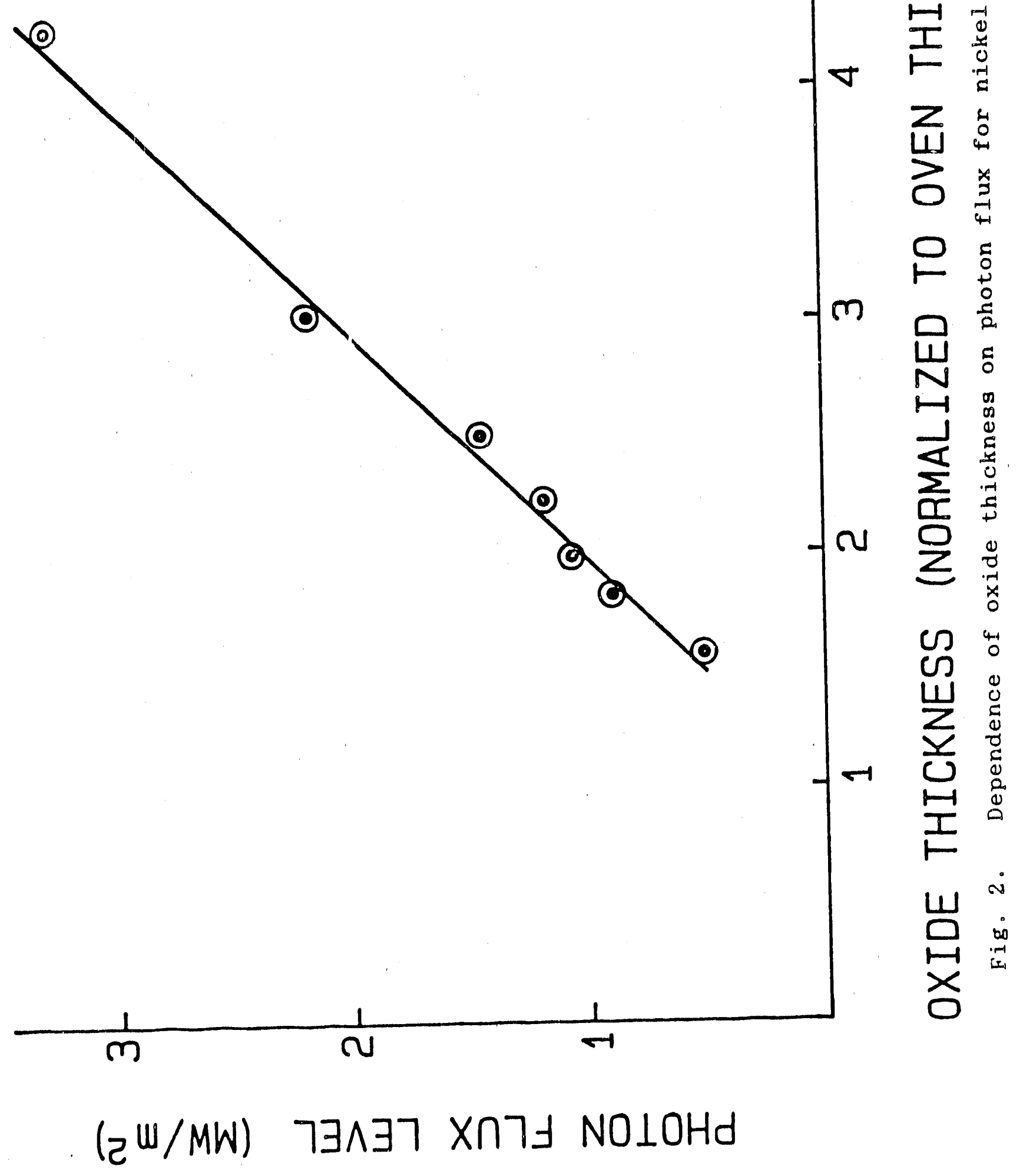


large desorption yields resulted in reduced oxidation of the chromium. It will be shown later how this will play a role in defining the high flux stability of stainless steels.

Nickel high flux studies led to one of the major discoveries of the program - high flux enhanced oxidation of materials. Nickel, when exposed to high flux irradiation $\left(0.5\right.$ to $\left.3.6 \mathrm{MW} / \mathrm{m}^{2}\right)$ at elevated temperatures ( 350 to $550^{\circ} \mathrm{C}$ ) unëergoes significantly enhanced oxidation. Samples were tested over the above noted range of fluxes and temperatures and have shown oxidation enhancements of up to $450 \%$ (Fig. 2 ).

Such enhancements could be the result of increased surface temperatures under solar irradiation as observed indirectly in the aluminum system. To test for this possibility, detailed experiments were undertaken utilizing low energy electron diffraction (LEED) to critically measure the surface temperature of a nickel single crystal exposed to high flux irradiation. LEED measures the average temperature of the top three or so atomic layers of the surface. Therefore, the LEED technique does not suffer from the depth uncertainty associated with infrared pyrometer or thermocouple measurements of surface temperature. It is also well to note that a material interacts with its environment through its atomic surface and that processes like oxidation occur in the top atomic layers of the material.

Figure 3 shows the experimental apparatus for the LEED measure- 


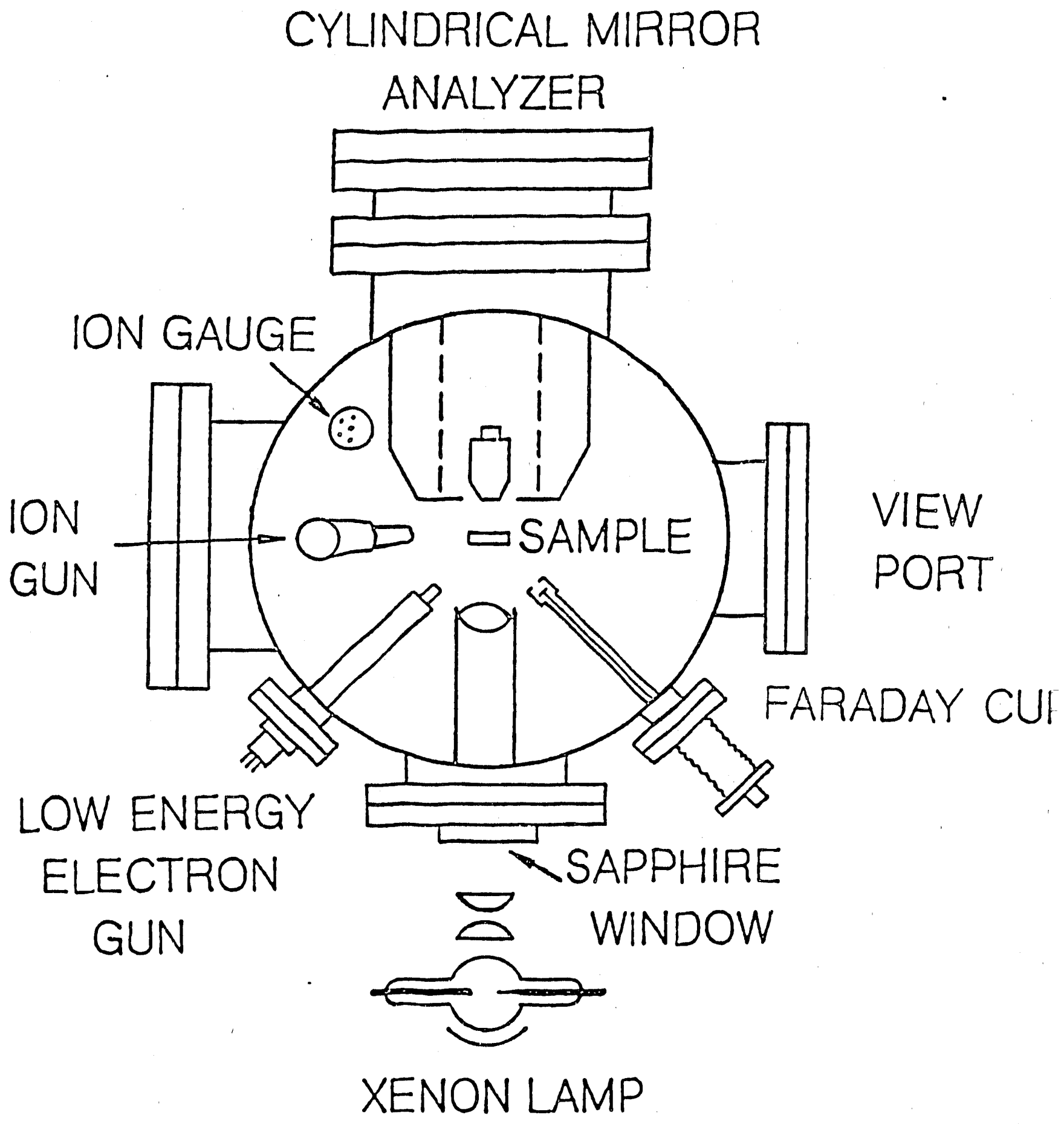

Figure 3. The experimental set-up used for the LEED experiments for the determination of surface temperature under high flux irradiation. The low energy electron gun and the Faraday cup are used for the experiments with the sample irradiated by the high power xenon lamp. 
ments. LEED intensity-energy profiles were measured as a function 0 . temperature under infrared, equilibriug heating conditions. These 'temperature standards' were then used to define the temperature of the surfare of the high flux solar irradiated sample. Table I lists the surface temperatures and bulk temperatures of an irradiated nickel sample under different levels of solar simulated flux. It should be noted that the data shows that the temperature difference between the actual surface temperature and the bulk sample temperature as measured by a thermocouple can be as large as $60^{\circ} \mathrm{C}$ at sample temperatures of -500 ${ }^{\circ} \mathrm{C}$ and fluxes of $\sim 2 \mathrm{MW} / \mathrm{m}^{2}$. This data well corroborates the work on aluminum which approximated a $100^{\circ} \mathrm{C}$ temperature difference between surface and bulk at a solar irradiation of $1.7 \mathrm{MW} / \mathrm{m}^{2}$.

The surface temperature difference of the order of $60{ }^{\circ} \mathrm{C}$, however, can not account for the several hundred percent increase of oxide thickness in the nickel. Nickel oxidation kinetics indicate that for nickel to have a $-400 \%$ increase in oxide thickness at $n$ bulk temperature of $400{ }^{\circ} \mathrm{C}$, the surface temperature must be at least $600^{\circ} \mathrm{C}$. This is outside the acceptable range of surface temperature enhancement undis high flux irradiation, and as a result, another mechanism must be responsible for the major enhancement in nickel oxidation.

Wavelength threshold measurements were subsequently undertaken in attempts to detcrminc the mechanism responsible. An eximer laser was used for this purpose as the solar simulator/monochrometer 


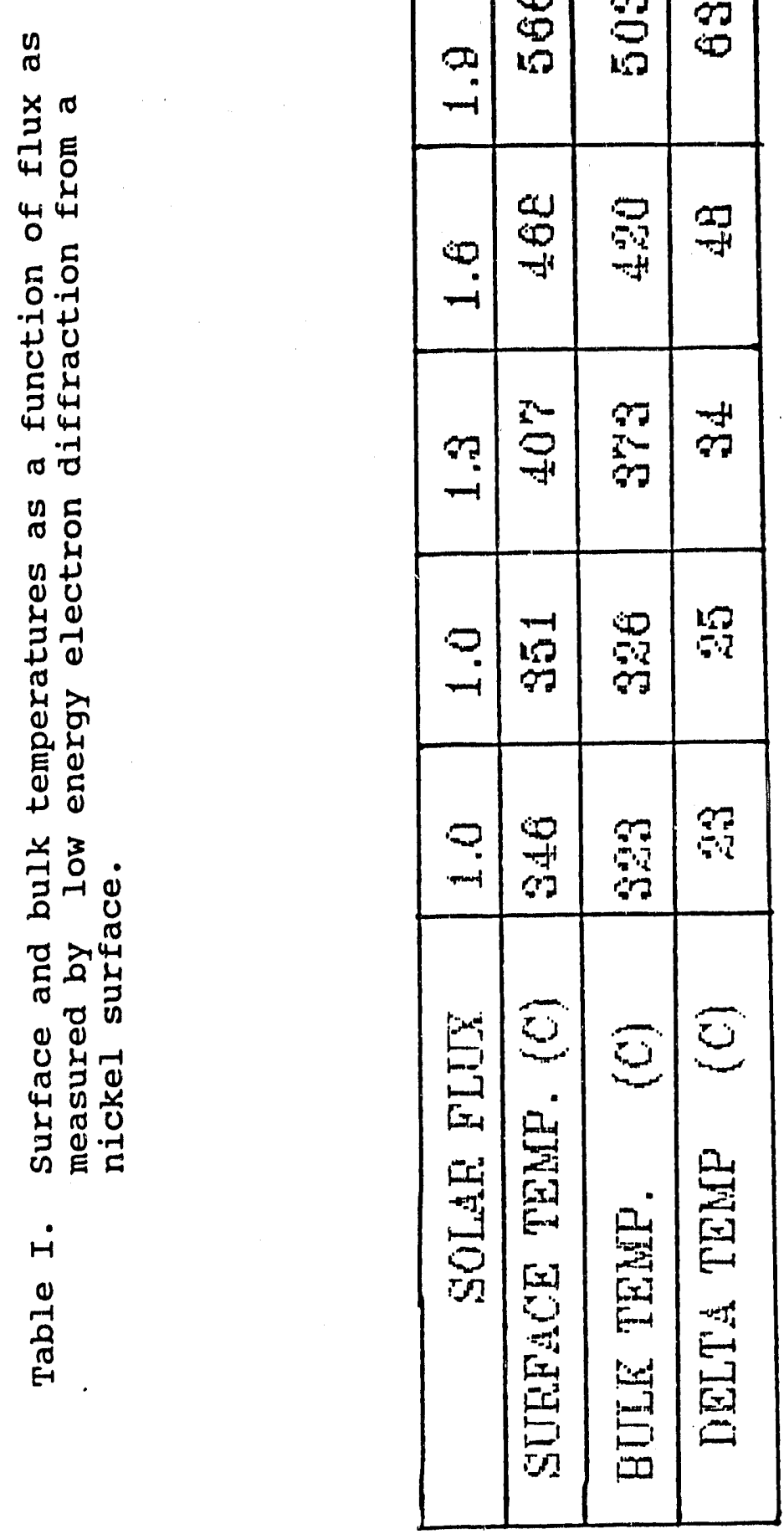


system used in the previous work did not yield adequate flux for oxidation enhancement measurements as a function of wavelength. Laser experiments yielded the data of Table II. Significant enhancement of oxidation was observed over the whole wavelength range with, however, decreased enhancement noted above $647 \mathrm{~nm}$. This decrease in high flux enhanced oxidation occurs near the excitation of the oxygen singlet sigma excited state, and points to the possibility of excited state chemistry playing a role in the observed photo-enhancament.

A singlet sigma excited state for the oxygen could make it more conducive to dissociation on the surface of the nickel/nickel oxide and result in a higher surface density of atomic oxygen yielding greater oxidation. The singlet sigma state at $762 \mathrm{~nm}$ $(1.63 \mathrm{ev})$, however, is not expected to be optically active with a cross section approaching $10^{-9}$. This is for the singlet state in molecular gas phase oxygen, and it may be affected by the chemisorptive character of the bonding of the molecule at the surface. The possibility is, therefore, strong that this excited state of oxygen, excited by the incident high flux solar radiation is responsible for the observed high flux oxidation enhancement in nickel.

With completion of the testing of the major elemental components of stainless-type steels, a series of stainless steel samples were subjected to high flux solar irradiation at elevated temperatures (Table III). All of the samples showed major enhance- 


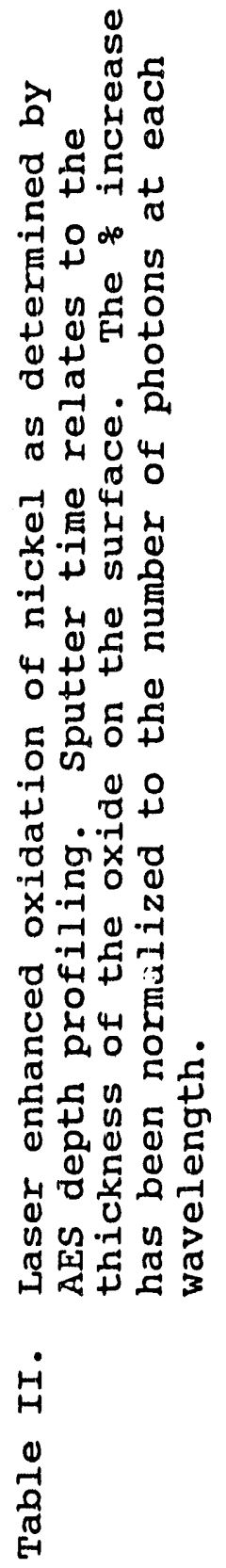

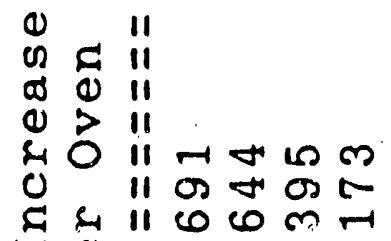

म्न

x 8

$\sim$ II

L $\&$ II

.

(1) E II 11 *

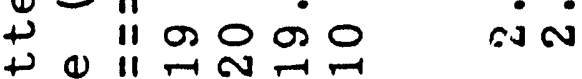

2 E II

Q.- II

CS E 11

c) 11

(1) II

a n 11 as as as a

\& 111 न न न

ON $\mathrm{II}++++$

$\downarrow E I I$ 되 되 되 [디

- $0116 \mathrm{~m} H$

E $\| \leftarrow \infty$ os

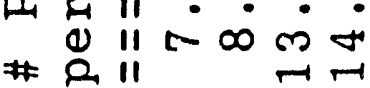

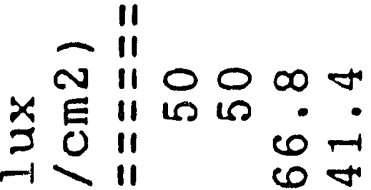

[1 311

II

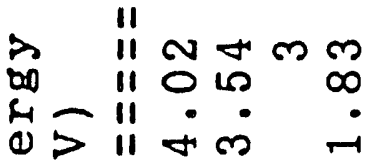

되 111

曲 $=$ II

\& E $111000 \%$

- 11 ल

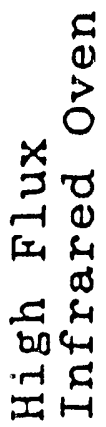




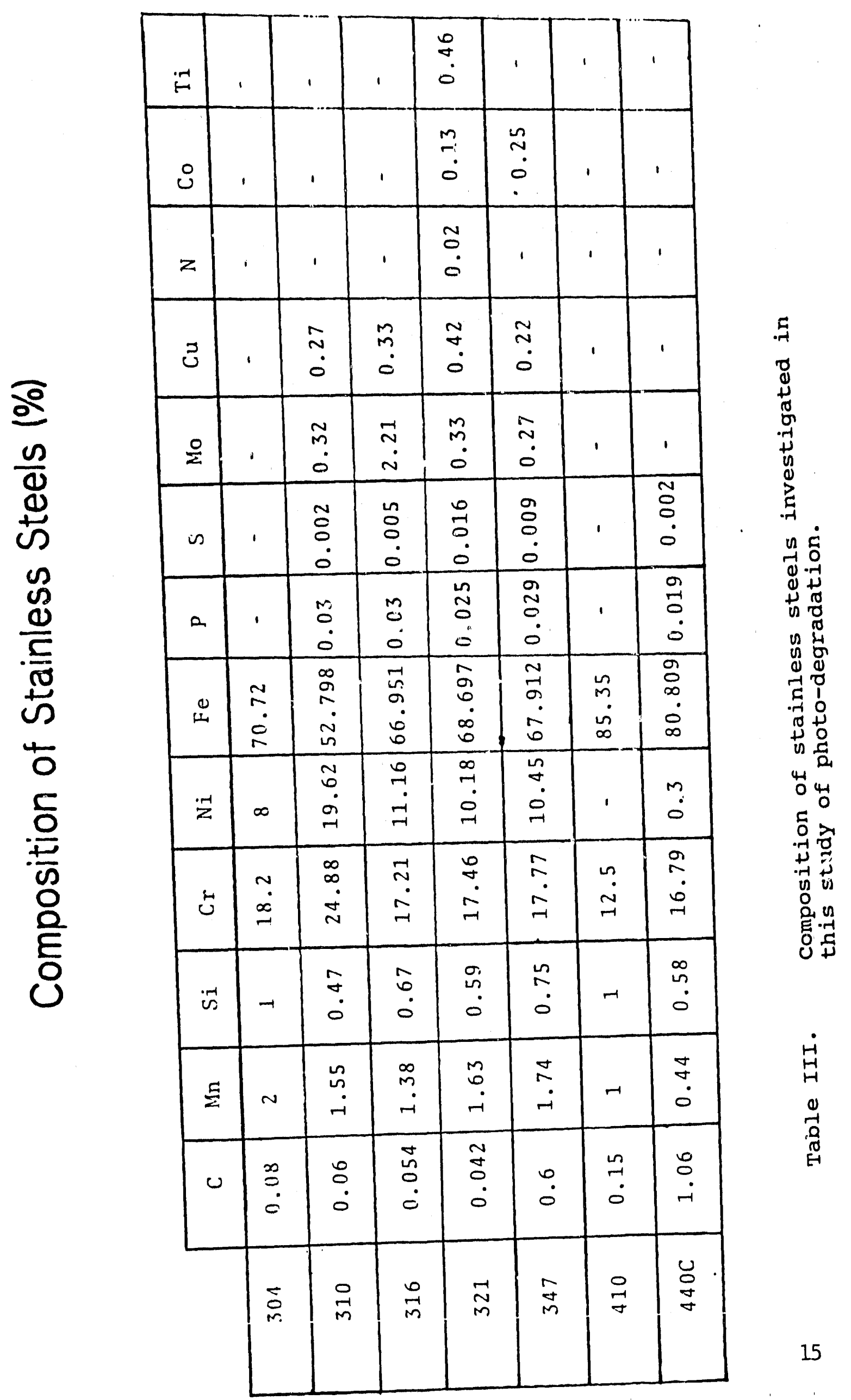


ments of oxidation under high flux irradiation. This was quite unexpected for the stainless steels since they were supposed to be high temperature stable systems. Detailed studies of the exposed samples through Auger electron spectroscopy depth profiling showed steels with the expected surface localized $\mathrm{Cr}_{2} \mathrm{O}_{3}$ oxidation barrier destroyed. The result was stainless steel which oxidized up to $1000 \%$ more under high flux irradiation than under infrared irradiation in equivalent conditions.

The ruechanism for the "loss" of the surface $\mathrm{Cr}_{2} \mathrm{O}_{3}$ layer was studied in detail and was determined to be the photodesorption of $\mathrm{CO}$ and $\mathrm{CO}_{2}$ species from the stainless steel's surface under high flux irradiation. The yields were measured to be in the range of $1 \times 10^{-4}$ to $1 \times 10^{-3}$ atoms per photon, and were similar to that found for $\mathrm{CO}$ and $\mathrm{CO}_{2}$ photodesorption from chrome oxide. The photodesorption, therefore, chemically reduced the surface localized chrome oxide thus removing the $\mathrm{Cr}_{2} \mathrm{O}_{3}$ anti-diffusion barrier present in the stainless steels and inducing high temperature oxidation of the iron underlayers.

A critical evaluation of the oxidation enhancement with flux was undertaken for the 304 stainless steel system. Samples were exposed at the Sandia Solar Furnace over a range of flux (from 0.6 to $2.6 \mathrm{MW} / \mathrm{m}^{2}$ ) at $500{ }^{\circ} \mathrm{C}$ for a period of $1 / 2$ hour. The data is shown in Figure 4. The data was analyzed for an analytic expression defining the oxidation behavior under high flux oxidation. An extremely good fit to the data was obtained for the 
expression:

$$
X=X_{0}+B F+A F^{2}
$$

$$
\text { where } \begin{aligned}
\mathrm{x}_{0} & =480 \mathrm{~A} \\
\mathrm{~B} & =19.4 \mathrm{Acm} / \mathrm{W} \\
\mathrm{A} & =0.13 \mathrm{~A} \mathrm{~cm} / \mathrm{W}^{2}
\end{aligned}
$$

The behavior is non-linear in flux and clearly indicates the major problems to be expected in the use of stainless steels under high flux levels. Note that even at nominal fluxes of 1 . $\mathrm{MW} / \mathrm{m}^{2}\left(100 \mathrm{~W} / \mathrm{cm}^{2}\right)$, the enhancement in oxidation can be up to $900 \%$, and that operation at flux levels can lead to oxidation enhancements of over $5000 \%$.

SUMMARY

In summary, the above noted studies have conclusively shown that high flux photo-irradiation of materials can result in significant changes in the stability of the materials. The major mechanisms have been determined to be photodesorption and photoenhanced oxidation. These mechanisms have been shown to affect, in extremely adverse ways, the expected thermal stability of solar relevant materials, especially stainless steels (it is expected that related high temperature alloy steels will be similarly affected), and an analytical expression has been generated to predict the flux behavior of the steels using \#304 as a 
prototypical stainless steel system.

ACKNOWLEDGEMENTS

The majority of the work described in this report was undertaken by the members of the Surface Physics group at the University of Houston. The contributors were: A. Bensaoula, E. Ekwelundu, J. Liu, A. Mesarwi, N. Nahar, T. Pavlovic and Y.Sun. The Department of Energy through the Solar Energy Research Institute is greatfully acknowledged for support of this work. Continued support and encouragement from L. Vant-Hull and A. Hildebrandt of the University of Houston Energy Laboratory and Solar Thermal Research center is greatfully acknowledged. Continued interest and added direction for the research program is greatfully acknowledged from G. Nix, W. Wilkins and H. Coleman. 
PUBLICATIONS RESULTING FROM THIS RESEARCH

1. "Solar Absorber Material Stability Under High Solar Flux", A. Ignatiev, G. Zajac, and G.B. Smith; SPIE vol. 324 (1982).

2. "The Dependence of the High Temperature, High Solar Flux stability of Materials on surface structure and Composition", A.Ignatiev; Proc. 2nd Intl. Conf. on Materials, Beer Sheva (1985).

3. "Photoeffects in Direct Flux Materials", A. Ignatiev; Direct Flux Workshop, Denver (1984).

4. "Surface Temperatures Under High Solar Flux Illumination", A.Mesarwí anid A. Ignatiev; Solar Energy Materials 11, 353 (1984).

5. "Photodesorption Studies from Aluminum oxide and from Adsorbates on Aluminum", A. Mesarwi and A. Ignatiev; J. Vac Sci. Technol. A3, 1641 (1985).

6. "Photodesorption Studies of Adsorbate Covered Aluminum Surfaces", A. Mesarwi and A. Ignatiev; Surface Science 166, $75(1986)$.

7. "Optical Tailoring of Solar Absorbers by Ion Implantation", J. S. Liu and A. Ignatiev; Solar Energy Materials 13, 399 (1986).

8. "Optical Properties of Spectrally Selective Anodically Coated Electrolytically Colored Aluminum Surfaces", T. Pavlovic and A. Ignatiev; Solar Energy Materials 16, 319 (1987).

9. "High Flux Degradation of Solar Materials: Stainless Steel", A. Mesarwi, Y. Sun and A. Ignatiev; Energy 12, 269 (1987)。

10. "Photo-enhanced Oxidation of Nickel", A.Mesarwi, A. Ignatiev and J.S. Liu; Sol. State Comm. 65, 319 (1988).

11. "Photodesorption from stainless Steels", A. Mesarwi and A.Ignatiev; J. Vac. Sci. T'echnol. (in print). 


\begin{tabular}{|c|c|c|c|c|}
\hline & $\begin{array}{l}\text { ocument Control } \\
\text { Page }\end{array}$ & $\begin{array}{l}\text { 1. SERI Report No. } \\
\text { SERI/TP-253-4282 }\end{array}$ & $\begin{array}{l}\text { 2. NTIS Accussion No. } \\
\text { DE91002147 }\end{array}$ & 3. Reciplent's Accession No. \\
\hline \multirow{2}{*}{\multicolumn{4}{|c|}{$\begin{array}{l}\text { 4. Title and Subtitle } \\
\text { Photodegradation Effects in Materials Exposed to High Flux Solar and } \\
\text { Solar Simulated Radiation }\end{array}$}} & $\begin{array}{l}\text { 5. Publication Date } \\
\text { April } 1992\end{array}$ \\
\hline & & & & 6. \\
\hline & $\begin{array}{l}\text { Author(s) } \\
\text { A. Ignatiev }\end{array}$ & & & $\begin{array}{l}\text { 8. Performing Organization Rept. } \\
\text { No. }\end{array}$ \\
\hline \multirow{2}{*}{\multicolumn{4}{|c|}{$\begin{array}{l}\text { 9. Portorming Organization Namo and Address } \\
\text { University of Houston } \\
4800 \text { Calhoun } \\
\text { Houston, Texas } 77004\end{array}$}} & 10. ProloctTask/Work Unit No. \\
\hline & & & & $\begin{array}{l}\text { 11. Contract (C) or Grant (G) No. } \\
\text { (C) X-7-07028-1 } \\
\text { (G) }\end{array}$ \\
\hline \multirow{2}{*}{\multicolumn{4}{|c|}{$\begin{array}{l}\text { 12. Sponsoring Organization Name and Address } \\
\text { Solar Energy Research Institute } \\
1617 \text { Cole Boulevard } \\
\text { Golden, Colorado } 80401-3393\end{array}$}} & $\begin{array}{l}\text { 13. Type of Report \& Period } \\
\text { Covered } \\
\text { Technical Report }\end{array}$ \\
\hline & & & & 14. \\
\hline \multicolumn{5}{|c|}{$\begin{array}{l}\text { 15. Supplementary Notes } \\
\text { SERI Technical Monitor: R. Gerald Nix, (303)231-1757 }\end{array}$} \\
\hline 16. & \multicolumn{4}{|c|}{$\begin{array}{l}\text { Abstract (Llmit: } 200 \text { words) } \\
\text { This report contains study results about photodegradation effects in materials exposed to high flux solar and } \\
\text { solar simulated radiation. The studies show that high flux photoirradiation of materials can result in significant } \\
\text { changes in the stability of materials. Photodesorption and photo-enhanced oxidation were determined to be the } \\
\text { major mechanisms. These mechanisms were shown to affect, in extremely adverse ways, the expected thermal } \\
\text { stability of solar relevant materials, especially stainless steels. (It is expected that related high temperature alloy } \\
\text { steels will be similarly affected.) An analytical expression was generated to predict the flux behavior of the } \\
\text { steels using \#304 as a prototypical stainless steel system. }\end{array}$} \\
\hline \multirow{2}{*}{\multicolumn{5}{|c|}{$\begin{array}{l}\text { 7. Document Analysis } \\
\text { a. Descriptors } \\
\text { Photodegradation } \\
\text { b. Identifiers/Open-E } \\
\text { c. UC Categories } \\
234\end{array}$}} \\
\hline & & & & \\
\hline \multirow{2}{*}{\multicolumn{3}{|c|}{$\begin{array}{l}\text { 18. Availability Statement } \\
\text { National Technical Information Service } \\
\text { U.S. Department of Commerce } \\
\text { 5285 Port Royal Road } \\
\text { Springfield, VA } 22161\end{array}$}} & & $\begin{array}{l}\text { 19. No. of Pages } \\
23\end{array}$ \\
\hline & & & & $\begin{array}{l}\text { 20. Price } \\
\mathrm{AO} 3\end{array}$ \\
\hline
\end{tabular}

Form No. 0069E (6-30.87) 

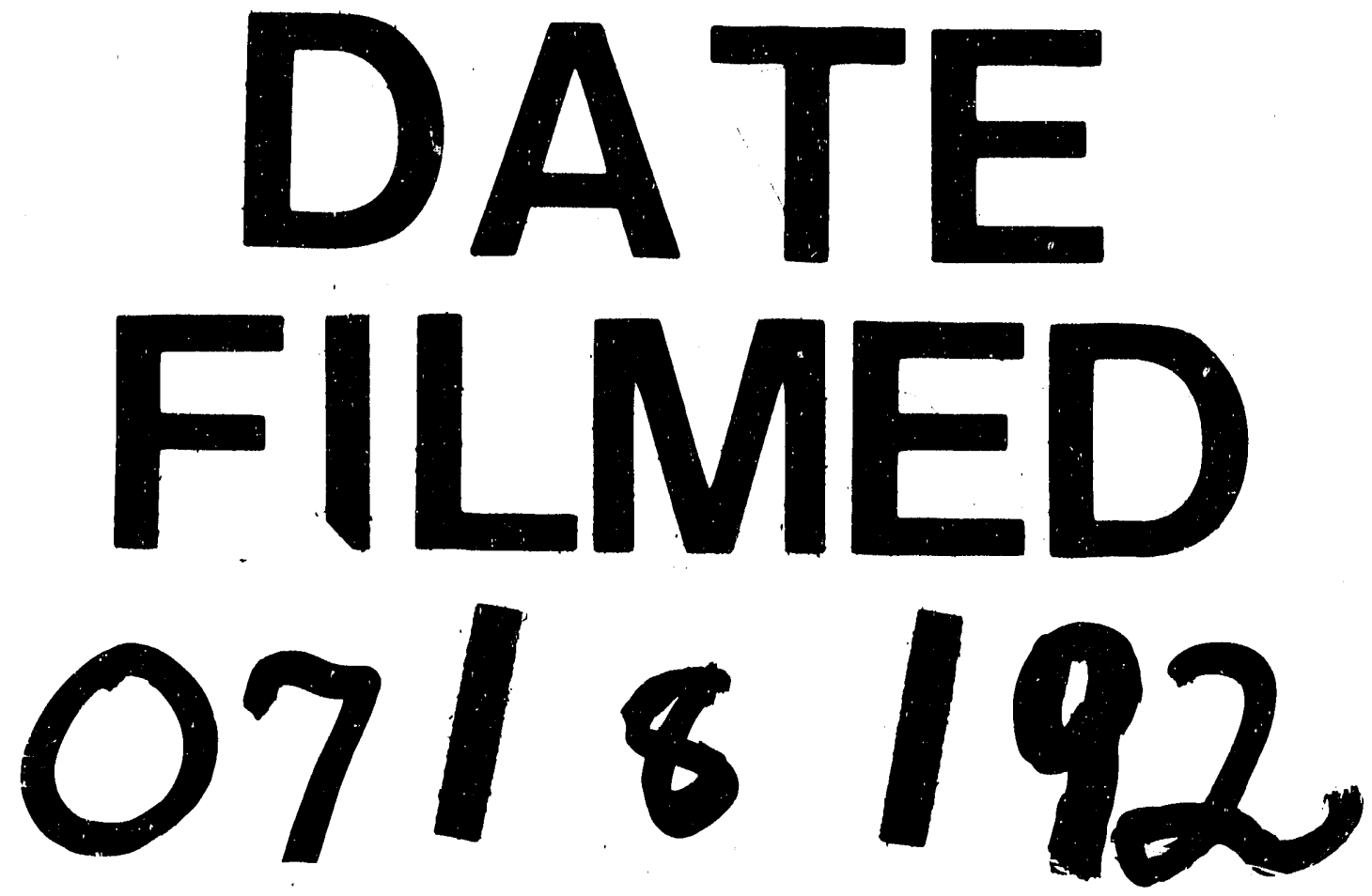
